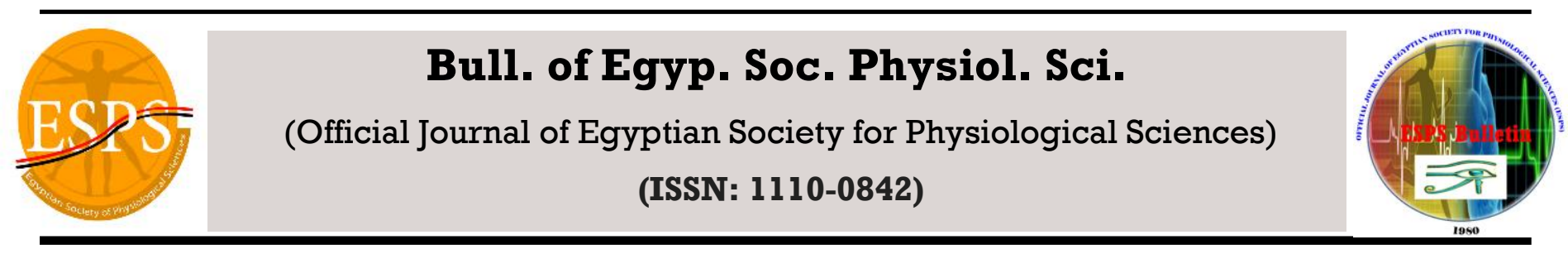

\title{
Effect Of L-Citrulline And Ranitidine On Indomethacin-Induced Gastric Ulcer In Male Albino Wister Rats
}

\author{
Mervat H. El-Saka, Abeer A. Abo Zeid, Ghada M. Abou Fard \\ Physiology Department, Faculty of Medicine, Tanta University
}

Received: May $1^{\text {st }} 2014$ Accepted: Aug 172104 Available online: Oct 5, 2014

\section{Keywords}

- L-citrulline

- Ranitidine

- Indomethacin

- Malondialdehyde

- Prostaglandin E2

- Myeloperoxidase

\begin{abstract}
Aim: to investigate the effect of L-citrulline and ranitidine (RAN) on indomethacin-induced gastric ulcer in male albino Wister rats. Methods: 50 male albino Wister rats were divided into 5 groups (10rats each): control received normal saline, indomethacin (IND) group; in which gastric ulceration was induced by a single dose of IND $(30 \mathrm{mg} / \mathrm{kg})$ intragastrically, IND+RAN group; pretreated with RAN (50mg/kg) intragastrically, IND+ L-citrulline group; pretreated with Lcitrulline $(900 \mathrm{mg} / \mathrm{kg})$ intragastrically, IND+RAN+L-citrulline group; received co-treatment with RAN and L-citrulline intragastrically. At the end of experiments, ulcer index (U.I.) and preventive index (P.I.) and gastric juice $\mathrm{pH}$, volume of gastric juice, free and total gastric acidity, pepsin activity and mucin content were assessed. Gastric homogenates were used for determination of Malondialdehyde (MDA), (nitrite/nitrate) NO content, prostaglandin E2 (PGE2), myeloperoxidase (MPO) activity and heme oxygenase (HO) activity. Results: pretreatment with either RAN or L-citrulline alone significantly reduced U.I. and also significantly reduced gastric juice volume, free and total acidity, pepsin activity, and gastric MDA with concomitant significant increase in $\mathrm{pH}$ of gastric juice. But, RAN insignificantly alter mucin content, NO content, PGE2, MPO activity and HO activity compared to IND group. While, pretreatment with L-citrulline alone significantly increased mucin content, NO content, PGE2, HO activity and significantly decreased MPO activity compared to either IND group or RAN group. Coadministration of RAN and L-citrulline resulted in more significant reduction of U.I. providing $87.30 \%$ prevention, and also more significant reduction of gastric juice volume, free and total acidity, pepsin activity, gastric MDA and MPO activity with concomitant more significant increase in $\mathrm{pH}$ of gastric juice and NO content, PGE2 synthesis and HO activity compared to either IND group or RAN groups. Conclusions: It could be concluded from this present study that the combination of L-citrulline and RAN afford a good gastroprotective potential against the gastric ulceration induced by IND better than each drug alone.
\end{abstract}

Corresponding author: Mervat H. El-Saka, Medical Physiology Department, Faculty of Medicine, Tanta University, Tanta, Egypt. E-mail: tantaphysiology@yahoo.com. Mobile: 01023126578 


\section{INTRODUCTION}

Gastric ulcer is one of the most serious diseases in the world (1). The etiology of gastric ulceration is multifactorial and not clearly defined, but some predisposing factors have been implicated (2). This include duration of starvation, nature of food ingested, bile reflux(3), lessened mucosal resistance(4), alteration of gastric mucosal blood flow(5), disruption of gastric mucosal barrier by stress(4), decrease in alkaline mucosal bicarbonate and mucus secretion(6), over dosage and/or prolonged administration of non-steroidal antiinflammatory drugs (NSAIDs)(7), persistent infection with Helicobacter pylori(8), Zollinger Ellison syndrome(9).

Pathophysiology of gastric ulcer occurs due to an imbalance between the aggressive factors (acid, pepsin and Helicobacter pylori) and the defensive factors (gastric mucus and bicarbonate secretion, prostaglandins, innate resistance of the mucosal cells) (10).

Indomethacin (IND), a potent NSAID was introduced in 1963 for the treatment of rheumatoid arthritis and related diseases $(11,12)$. A reduction in the biosynthesis of prostaglandin (PG) is the pharmacological background to both the antiinflammatory action and the harmful side effects of IND and other NSAIDs (13). The gastrointestinal adverse effects of NSAIDs, especially in the stomach, are one of the most serious complications in patients taking these drugs (14).

Citrulline is a non-essential amino acid in mammals, closely related to biosynthesis of Larginine (15). It is readily converted to L-arginine, in the kidney, vascular endothelium and other tissues, thus raising its plasma and tissue levels (16). It has been demonstrated that L-arginine can elicit a gastroprotective effect by preventing the inducible NOs activity in the gastric mucosa of rats with water immersion restraint for treatment of gastric ulcer (17). Citrulline was first identified from the juice of watermelon (18). It was later obtained from tyrptic digestion of casein (19). In most mammals, the small intestine is the major source of circulating citrulline which is utilized in the endogenous synthesis of arginine (20).

Citrulline is a co-product of nitric oxide synthesis (21). Nitric oxide (NO) functions as a cellular messenger in the cardiovascular system and is a pivotal vasoprotection molecule (22). Also, NO inhibits gastric acid secretion (23), and also enhances plasma concentrations of pancreatic glucagon, which is a physiological inhibitor of gastric acid secretion (24).

A widely used drug associated with rare idiosyncratic hepatotoxicity is the histamine $\mathrm{H} 2$ receptor antagonist ranitidine (RAN)(25). Idiosyncratic RAN occurs in few people taking the drug. However, extensive liver damage has occurred in individuals undergoing RAN therapy (26). Thus, there is need for more effective and safe antiulcer agents.

Some previous experimental studies have been performed to evaluate the anti-ulcer effect of Lcitrulline, however, this study was undertaken to assess the effect of both L-citrulline and ranitidine, separately and combined together on indomethacin-induced gastric ulcer in male albino Wister rats, and also to assess other possible mechanisms for the anti-ulcer activity of Lcitrulline, rather than it is $\mathrm{NO}$ inducer. 


\section{MATERIALS AND METHODS}

\section{Animals:}

This study was carried out on 50 male albino rats of Wister strain, 12-16 weeks old, weighing about (180-220gm) were housed, in groups of 5 rats in each cage, under standard laboratory conditions at room temperature $\left(28 \pm 2^{\circ} \mathrm{C}\right)$ with $12 \mathrm{~h}$ light and $12 \mathrm{~h}$ dark cycles. The rats had free access to water and food. All the experiments were performed during the same time of day, between 9 a.m. and 12 p.m. to avoid variation due to diurnal rhythms (27).

\section{Drugs and chemicals:}

Indomethacin was obtained from sigma pharmatheutical industries Egypt. Ranitidine was provided by Glaxosmith Kline, Egypt. L-citrulline was obtained from Sigma chemical Co.

\section{Experimental design:}

All rats were fasted for $24 \mathrm{~h}$ prior to the induction of gastric ulcer, but allowed free access to water except for the last hour before the induction of gastric ulcer. The animals were divided into five groups (10rats each): Group I (control group); Rats in this group received normal saline $1 \mathrm{ml} / \mathrm{rat}$ via intragastric tube for 7 days.

Group II (IND group); In which gastric ulceration was induced by a single dose of IND $(30 \mathrm{mg} / \mathrm{kg})$ and given via an intragastric tube $(28)$.

Group III (IND+RAN group); In which animals pretreated with RAN in a dose of $50 \mathrm{mg} / \mathrm{kg}$ body weight intragastrically (29).

Group IV (IND+ L-citrulline group); In which animals were pretreated with $900 \mathrm{mg} / \mathrm{kg}$ of Lcitrulline(30) intragastrically.
Group V (IND+RAN+ L-citrulline); in which the animals concurrently pretreated with RAN and L-citrulline intragatrically.

All pretreatments in groups (III, IV,V) given for 7 days prior to the induction of the gastric ulcer by IND administration.

\section{Pyloric ligation:}

After one week of the treatment either normal saline, RAN or L-citrulline, all animals were subjected to pyloric ligation as described by Alumets et al.(31) one hour before induction of gastric ulcer in (groups II, III,IV\& V). Under pentobarbitone anesthesia $\quad(40 \mathrm{mg} / \mathrm{kg}$ intrapertoneally), a mid-line abdominal incision was performed and the pyloric portion of the stomach was gently mobilized and ligated with a silk ligature. The needle was passed along the upper border of the pylorus behind its posterior surface avoiding the gastroduodenal artery and passed out on its lower border where it crosses the omentum. The ligature was tied in order to close the pylorus without crushing its wall. The abdominal incision was sutured and the animals were allowed to recover from anesthesia for a period of one hour.

\section{Assessment of gastric mucosal lesions:}

The animals were sacrificed by cervical decapitation 4h after IND administration (27). Each stomach was removed and opened along the greater curvature, and the gastric juice was collected. The stomachs were washed with icecold saline and examined for macroscopic mucosal lesions with the help of magnifying lens. The mucosal lesions were expressed in terms of ulcer index (U.I.) according to Peskar et al.(32) which depends on the calculation of a lesion index using a 0-3 scoring system based on the severity of each 
lesion. The severity factor was defined according to the length of the lesions. Severity factor $0=$ no lesions; $1=$ lesions $<1 \mathrm{~mm}$ length; $2=$ lesions $2-4$ mm length and $3=$ lesions $>4 \mathrm{~mm}$ length. The lesions score for each rat was calculated as the number of lesions in the rat multiplied by their respective severity factor. The U.I. for each group was taken as the mean lesion score of all the rats in that group. The preventive index (P.I.) of a given drug was calculated by the equation of Hano et al.(33)

P.I. $=\frac{\text { U.I of IND group - U.I.of pretreatedgroup }}{\text { U.I.of IND group }} \times 100$

\section{Analysis of gastric juice:}

At the end of experiment, $4 \mathrm{~h}$ after induction of gastric ulceration in (groups II, III,IV\& V) and in the normal control, the gastric juice was collected from each animal and centrifuged at $3000 \mathrm{rpm}$ for $10 \mathrm{~min}$. to remove any solid debris and the volume was measured. The supernatant was then assayed for $\mathrm{pH}$ according to Moore(34), free and total acid outputs were measured respectively by Hara et al.(35) and Feldman(36) and the results were expressed in milliequivalent per liter $(\mathrm{mEq} / \mathrm{L})$, pepsin activity according to Sanyal et al.(37) and the results were expressed in $\mu \mathrm{g} / \mathrm{ml}$ tyrosine and mucin content was measured by Beneyto and Colomé(38) and the results were expressed in $\mathrm{mg} \%$ hexose.

\section{Biochemical analysis of gastric mucosa:}

The homogenate of gastric tissue was used for assay of Malondialdehyde (MDA) level according to the method of Mihara and Uchiyama(39) and the results were expressed in $\mathrm{nmol} / \mathrm{g}$ tissue, NO content was determined as total nitrite/nitrate, the stable degradation products of NO according the method of Sastry et al.(40) and the results were expressed in $\mathrm{nmol} / \mathrm{g}$ tissue, prostaglandin $\mathrm{E} 2$ (PGE2) assay was performed with PGE2 enzyme immunoassay kit according to Arvind et al.(41), and the results were expressed in $\mathrm{ng} / \mathrm{g}$ tissue, myeloperoxidase (MPO) activity, a marker of neutrophil infiltration, was assayed according to the method of Bradley et al.(42) and the results were expressed in units/g tissue and Heme oxygenase (HO) activity was measured, as the ability of tissue homogenates to metabolize heme to bilirubin, according to Ishikawa et al.(43), HO activity was expressed as $\mu \mathrm{g}$ of bilirubin formed/mg protein per hour.

\section{Statistical analysis:}

The data were expressed as the mean \pm standard deviation. Data from our study were analyzed using the unpaired student's t-test to assess significant difference between two groups. Statistical comparison between different groups was carried out by using one-way ANOVA. Significant results of analysis of variance were subjected to post hoc analysis (Tukey-Kramer multiple comparisons). P-values $<0.05$ were considered statistically significant. All the analyses were performed using Graph Pad Instat, 32 bit for win 95/NT (Version 3.05).

\section{RESULTS}

Effect of RAN and L-citrulline on gastric U.I. \& P.I.:

As shown in table 1, IND administration caused a remarkably high U.I. (25.2 \pm 1.87$)$ when compared to normal control group $(1.1 \pm 0.74)$. Pretreatment with RAN or L-citrulline offered significant protection against IND-induced gastric 
Table (1): Effect of RAN and L-citrulline pretreatment, and their combination on U.I. and P.I. in IND-induced gastric ulcer in male albino Wister rats

\begin{tabular}{|l|c|c|}
\hline \multicolumn{1}{|c|}{ Groups } & U.I. & P.I. \\
\hline Control & $1.1 \pm 0.74$ & - \\
\hline IND & $25.2 \pm 1.87^{\mathrm{a}}$ & - \\
\hline IND+RAN & $10.2 \pm 1.03^{\mathrm{a}, \mathrm{b}}$ & $59.52 \%$ \\
\hline IND+ L-citrulline & $8.6 \pm 1.43^{\mathrm{a}, \mathrm{b}, \mathrm{c}}$ & $65.87 \%$ \\
\hline IND+RAN +L-citrulline & $3.2 \pm 0.79^{\mathrm{a}, \mathrm{c}, \mathrm{d}, \mathrm{d}}$ & $87.30 \%$ \\
\hline
\end{tabular}

Data are given as mean \pm SD. $\quad{ }^{\mathrm{a}} \mathrm{P}<0.05$ vs control group. ${ }^{\mathrm{b}} \mathrm{P}<0.05$ vs IND group. $\quad{ }^{\mathrm{c}} \mathrm{P}<0.05$ vs IND+RAN group. ${ }^{\mathrm{d}} \mathrm{P}<0.05$ vs IND+ L-citrulline group.

ulcer in the experimental rats, RAN reduced U.I.

to $(10.2 \pm 1.03)$ showing $59.52 \%$ prevention.

Whereas, L-citrulline reduced U.I. to $(8.6 \pm 1.43)$ showing $65.87 \%$ prevention. Pretreatment of rats with both RAN and L-citrulline produced higher
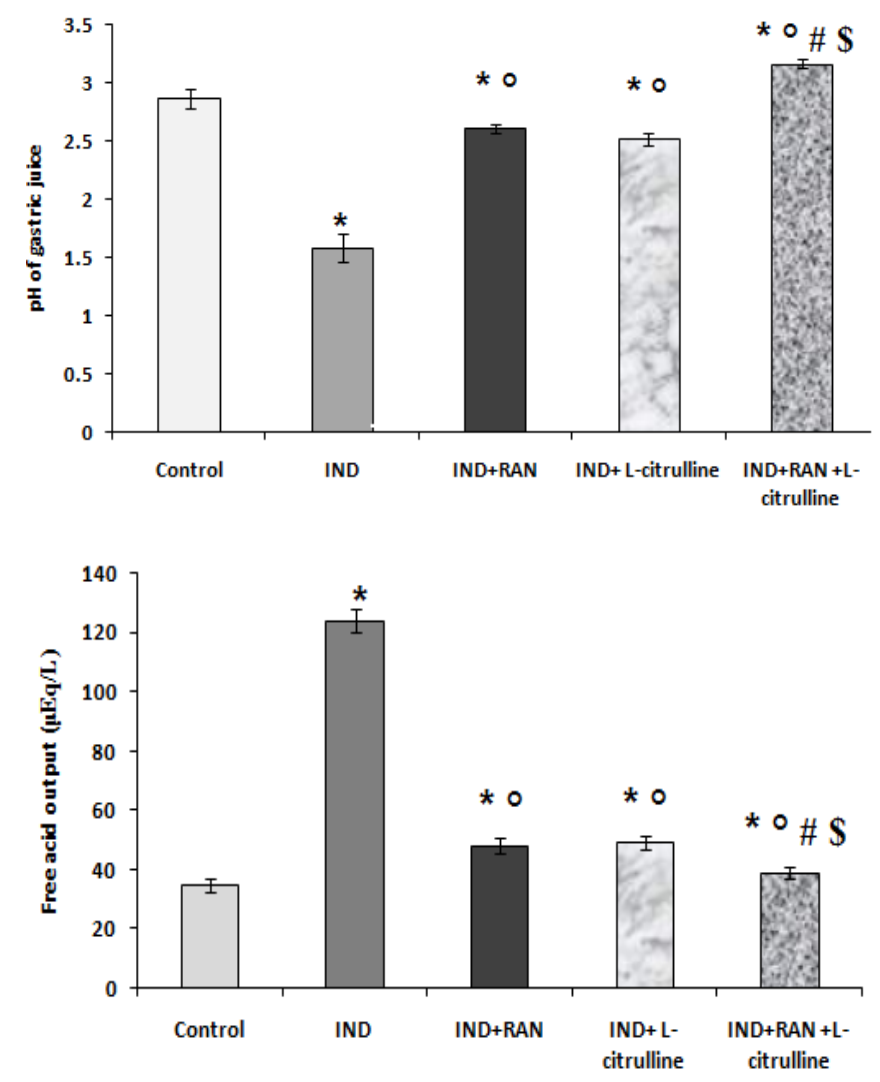

Figure (1): Effect of RAN and L-citrulline pretreatment, and their combination on volume, pH, free and total acid output of the gastric juice in IND-induced gastric ulcer in male albino Wister rats. Data are given as mean $\pm \mathrm{SD} .{ }^{*} \mathrm{P}<0.05$ vs control group. ${ }^{\circ} \mathrm{P}<0.05$ vs IND group. ${ }^{\#} \mathrm{P}<0.05$ vs IND+RAN group. ${ }^{\$} \mathrm{P}<0.05$ vs IND+ L-citrulline group.

\section{Effect of RAN and L-citrulline on gastric juice} analysis:

IND administration caused significant decrease in $\mathrm{pH}$ value of gastric juice associated with significant increase in volume of gastric juice and
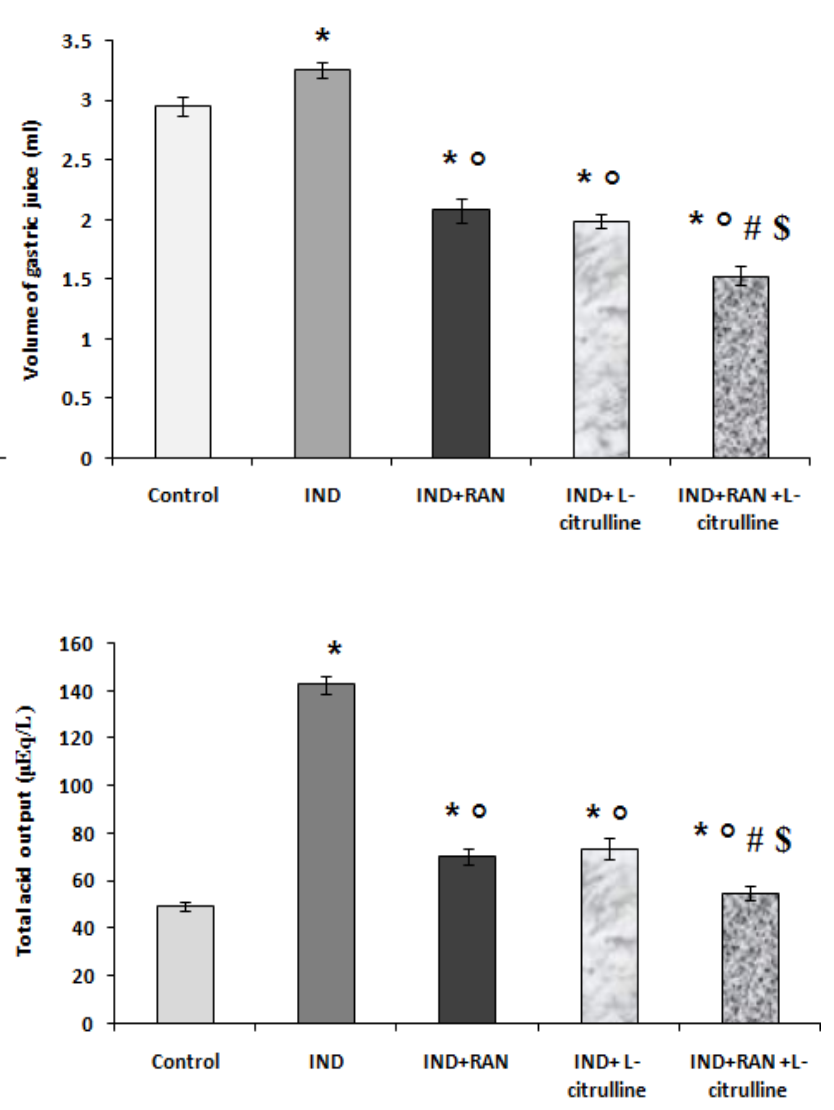

gastroprotective effect as compared to RAN or Lcitrulline alone, significantly decreased the U.I. to (3.2 \pm 0.79$)$ providing $87.30 \%$ prevention against gastric mucosal injury. 
as compared to IND group. Co-administration of RAN and L-citrulline showed more significant increase in $\mathrm{pH}$ associated with potent efficacy in

Figure 2 shows that IND administration caused significant increase in gastric pepsin activity associated with significant reduction in gastric mucin content as compared to the normal control group. Pretreatment with either RAN or Lcitrulline alone significantly decreased the gastric pepsin activity as compared to IND group. Coadministration of RAN and L-citrulline showed more efficient reduction in pepsin activity as compared to RAN or L-citrulline alone. Pretreatment with RAN did not produce any significant change in mucin content as compared to IND group, while, L-citrulline alone or its coadministration with RAN significantly increased mucin content as compared to either IND group or RAN pretreated group.

Effect of RAN and L-citrulline on gastric mucosal MDA levels:

As shown in table 2, administration of IND significantly elevated the gastric MDA levels $(109.80 \pm 8.58 \mathrm{nmol} / \mathrm{g}$ tissue) as compared to the normal control group $(47.23 \pm 8.16 \mathrm{nmol} / \mathrm{g}$ tissue). Interestingly, all pretreatments which used produced significant reduction in gastric MDA levels as compared to IND group. RAN pretreatment reduced the gastric MDA levels to $(58.20 \pm 8.61 \mathrm{nmol} / \mathrm{g}$ tissue), while, L-citrulline pretreatment reduced MDA levels to $(53.44 \pm 6.66 \mathrm{nmol} / \mathrm{g}$ tissue), co-administration of RAN and L-citrulline significantly augmented the decrease of gastric MDA levels to $(42.42 \pm 7.70 \mathrm{nmol} / \mathrm{g}$ tissue $)$ reduction of volume of gastric juice, and free and total acid output as compared to RAN or Lcitrulline alone (table 2).

\section{Effect of RAN and L-citrulline on gastric mucosal PGE2 levels:}

The synthesis of mucosal PGE2 was markedly suppressed by IND as compared to the normal control rats. RAN pretreatment insignificantly affected PGE2 synthesis as compared to IND group. However, the mucosal synthesis of PGE2 increased significantly due to pretreatment with either L-citrulline alone or its combination with RAN compared to either IND group or RAN pretreated group (table 2).

\section{Effect of RAN and L-citrulline on gastric mucosal nitrites/nitrates content:}

As compared to the normal control group, gastric mucosal nitrites/nitrates content was significantly reduced from $(269.4 \pm 5.50 \mathrm{nmol} / \mathrm{g}$ tissue $)$ to $(198.0 \pm 5.16 \mathrm{nmol} / \mathrm{g}$ tissue) in IND group. Pretreatment with RAN failed to alter significantly the gastric mucosal nitrites/nitrates content (205.1 $\pm 10.35 \mathrm{nmol} / \mathrm{g}$ tissue) when compared to IND group. While, pretreatment with L-citrulline significantly increased the gastric mucosal nitrites/nitrates content $(285.3 \pm 4.11 \mathrm{nmol} / \mathrm{g}$ tissue $)$ when compared to either IND group or RAN pretreated group. More significant increase in the gastric mucosal nitrites/nitrates content $(298.3 \pm 2.75 \mathrm{nmol} / \mathrm{g}$ tissue $)$ was observed when RAN co-administered with L-citrulline as compared to either IND group, RAN pretreated group or L-citrulline pretreated group(table 2). 
Effect of RAN and L-citrulline on gastric mucosal MPO activity in gastric tissue:

The activity of gastric mucosal MPO was significantly increased in the IND group $(0.773 \pm 0.011$ unit/g tissue) as compared to the normal control group $(0.198 \pm 0.010$ unit/g tissue). Pretreatment with RAN produced insignificant change in MPO activity $(0.722 \pm 0.083$ unit/g tissue $)$ compared to IND group. While, L-citrulline alone or its co-treatment with RAN produced more significant reduction in MPO activity $(0.289 \pm 0.032 \mathrm{unit} / \mathrm{g}$ tissue $)$ and $(0.238 \pm 0.032 \mathrm{unit} / \mathrm{g}$ tissue) respectively as compared to either IND group, RAN pretreated group (table 2).
Effect of RAN and L-citrulline on gastric mucosal HO activity in gastric tissue:

Fig. 3 showed that the activity of gastric mucosal HO was insignificantly changed in IND group $(0.048 \pm 0.022 \mu \mathrm{g} / \mathrm{mg}$ protein $/ \mathrm{h})$ as compared to the normal control group $(0.105 \pm 0.021 \mu \mathrm{g} / \mathrm{mg}$ protein/h). Also, pretreatment with RAN insignificantly altered HO activity $(0.098$ $\pm 0.025 \mu \mathrm{g} / \mathrm{mg}$ protein $/ \mathrm{h}$ ) compared to IND group. While, L-citrulline alone or its combination with RAN produced significant increase in $\mathrm{HO}$ activity $(0.326 \pm 0.066 \mu \mathrm{g} / \mathrm{mg} \quad$ protein $/ \mathrm{h}) \quad$ and $(0.337 \pm 0.067 \mu \mathrm{g} / \mathrm{mg}$ protein $/ \mathrm{h})$ respectively as compared to either IND group or RAN pretreated group.
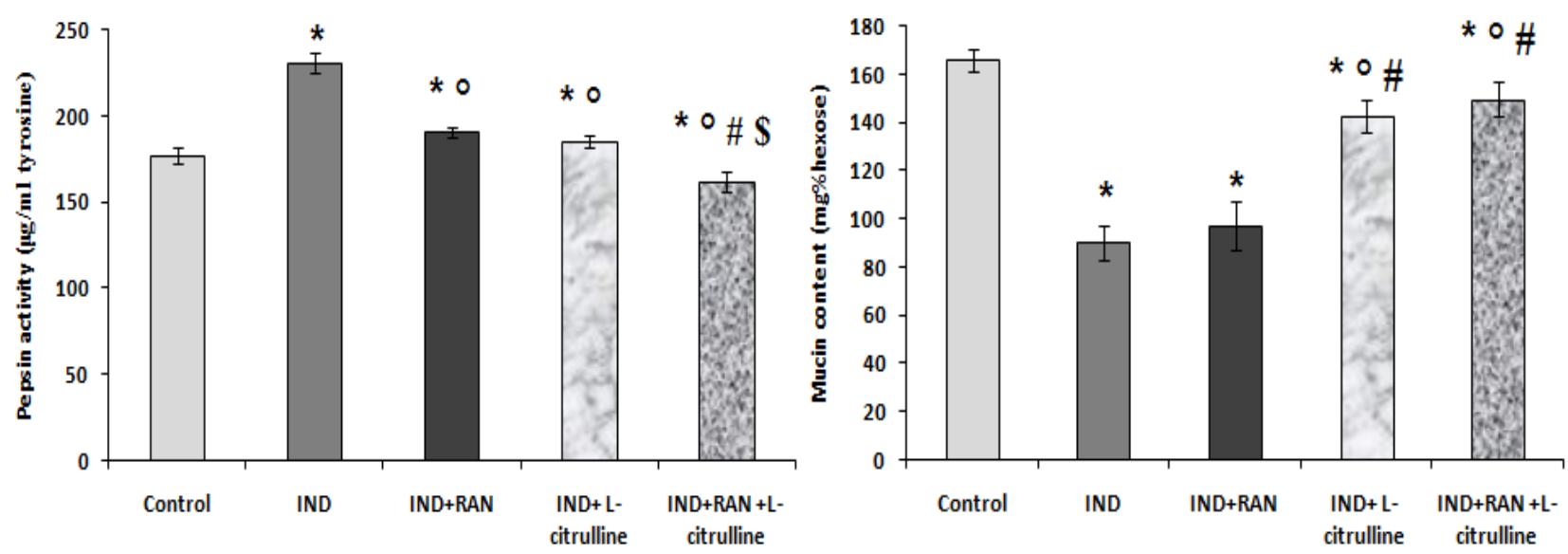

Figure (2): Effect of RAN and L-citrulline pretreatment, and their combination on pepsin activity and mucin content in IND-induced gastric ulcer in male albino Wister rats. Data are given as mean $\pm \mathrm{SD} . \quad * \mathrm{P}<0.05$ vs control group. ${ }^{\circ} \mathrm{P}<0.05$ vs IND group. \#P $<$ 0.05 vs IND+RAN group. $\$$ P $<0.05$ vs IND+ L-citrulline group.

Table(2): Effect of RAN and L-citrulline pretreatment, and their combination on MDA and PGE2 nitrite/nitrate and MPO levels in IND-induced gastric ulcer in male albino Wister rats

\begin{tabular}{|l|c|c|c|c|}
\hline \multicolumn{1}{|c|}{ Groups } & $\begin{array}{c}\text { MDA } \\
\text { (nmol/g tissue) }\end{array}$ & $\begin{array}{c}\text { PGE2 } \\
(\mathbf{n g} / \mathbf{g} \text { tissue) }\end{array}$ & $\begin{array}{c}\text { Nitrite/nitrate } \\
\text { (nmol/g tissue) }\end{array}$ & MPO (unit/g tissue) \\
\hline Control & $47.23 \pm 8.16$ & $505 \pm 30.28$ & $269.4 \pm 5.50$ & $0.198 \pm 0.010$ \\
\hline IND & $109.80 \pm 8.58^{\mathrm{a}}$ & $303 \pm 15.85^{\mathrm{a}}$ & $198.0 \pm 5.16^{\mathrm{a}}$ & $0.773 \pm 0.011^{\mathrm{a}}$ \\
\hline IND+RAN & $58.20 \pm 8.61^{\mathrm{a}, \mathrm{b}}$ & $309.4 \pm 17.60^{\mathrm{a}}$ & $205.1 \pm 10.35^{\mathrm{a}}$ & $0.722 \pm 0.083^{\mathrm{a}}$ \\
\hline IND+ L-citrulline & $53.44 \pm 6.66^{\mathrm{b}}$ & $482 \pm 35.21^{\mathrm{b}, \mathrm{c}}$ & $285.3 \pm 4.11^{\mathrm{a}, \mathrm{b}, \mathrm{c}}$ & $0.289 \pm 0.032^{\mathrm{a}, \mathrm{b}, \mathrm{c}}$ \\
\hline IND+RAN +L-citrulline & $42.42 \pm 7.70^{\mathrm{b}, \mathrm{c}, \mathrm{d}}$ & $491 \pm 33.48^{\mathrm{b}, \mathrm{c}}$ & $298.3 \pm 2.75^{\mathrm{a}, \mathrm{b}, \mathrm{c}, \mathrm{d}}$ & $0.238 \pm 0.032^{\mathrm{b}, \mathrm{c}}$ \\
\hline
\end{tabular}

Data are given as mean \pm SD. $\quad{ }^{\text {a }} \mathrm{P}<0.05$ vs control group. ${ }^{b} \mathrm{P}<0.05$ vs IND group. ${ }^{c} \mathrm{P}<0.05$ vs IND+RAN group. ${ }^{\mathrm{d}} \mathrm{P}<0.05$ vs IND+ L-citrulline group 


\section{DISCUSSION}

NSAIDs are one of the most widely used classes of drugs in the world (12). NSAIDs-induced gastric ulceration is the major side effect of this kind of drugs(14). Therefore, drugs that have the potential to reduce NSAIDs side effects should be selected for patients taking NSAIDs concomitantly for treatment of other medical conditions(7).

In the present study, IND administration induced severe gastric mucosal ulcerations, which were accompanied by significant increase in U.I., volume of gastric juice, free and total acidity, pepsin activity, gastric MDA and MPO activity with concomitant reduction in $\mathrm{pH}$ of gastric juice, mucin content, NO (nitrite/nitrate) and PGE2 levels compared to the normal control rats, and insignificantly affect $\mathrm{HO}$ activity as compared to the normal control.

The gastrotoxic effects of NSAIDs, including IND are attributed to the non-selective inhibition of cyclooxygenases (COX1and COX2) with subsequent reduction in $\mathrm{PGs}$ production, which believed to have potent anti-ulcer and cytoprotective properties (13). Ulceration due to IND could also be due to its ability to induce reactive oxygen metabolites, which may in turn promote lipid peroxidation and gastric damage (12).

The results of the present work showed that oral administration of RAN significantly reduced the U.I. showing $59.52 \%$ prevention, also significantly reduced the volume of gastric juice, free and total acidity and pepsin activity. However, the drug has not produced any significant quantitative change in mucin content. These finding are in agreement with the results obtained by Kalra et al.(44). The effect of RAN is mediated through histamine $\mathrm{H} 2$ receptors. H2 receptors on the parietal cell mediates the stimulatory effect of histamine on acid secretion(45). RAN, a histamine H2 receptor antagonist, blocks the H2-receptors resulting in a decrease in the secretory actions of gastrin and acetylcholine on the parietal cells (46).

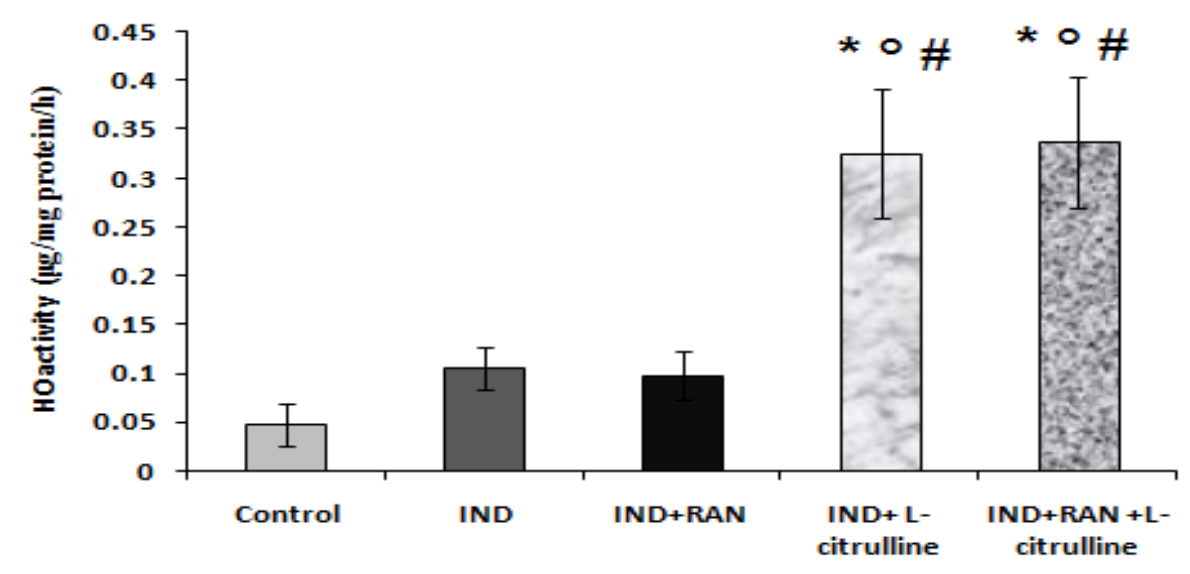

Figure (3) Effect of RAN and L-citrulline pretreatment, and their combination on HO activity in IND-induced gastric ulcer in male albino Wister rats. Data are given as mean $\pm \mathrm{SD} . \quad{ }^{*} \mathrm{P}<0.05$ vs control group. ${ }^{\circ} \mathrm{P}<0.05$ vs IND group. $\quad$ \# $\mathrm{P}<0.05$ vs IND+RAN group. ${ }^{\$} \mathrm{P}<0.05$ vs IND+ L-citrulline group.

Our present study demonstrated that intragastric administration of L-citrulline, for 7 days before induction of gastric ulceration by IND, resulted in significant decrease in U.I. showing $65.87 \%$ prevention, also significantly reduced volume of gastric juice, free and total acidity and pepsin 
activity with concomitant increase of $\mathrm{pH}$ of gastric juice and mucin content.

The mechanism which underlie the gastroprotection of L-citrulline might be attributed to its direct antioxidant and free radical scavenging activity(47), or indirectly due to augmentation of the intracellular reduced glutathione, reduced glutathione peroxidase and superoxide dismutase in the rat gastric tissues, all of which can scavenge superoxide, hydrogen peroxide, hydroxyl and lipid peroxyl radicals and attenuate damages to the tissues(48). In addition, the gastroprotection of Lcitrulline might be due to the recycling pathway from L-citrulline to L-arginine and $\mathrm{NO}(25)$. The recycling pathway might be crucial in sustaining the production of NO, which may be important for the integrity of the gastric mucosa in health and disease through its anti-microbial actions and by influencing mucus production by the gastric mucosa (49).

Also, in our present study, the significant decrease of the peptic activity of L-citrulline as compared to IND group may be attributed to the detected increase in gastric juice $\mathrm{pH}$ as gastric acidity is essential for cleavage of pepsinogen to the active pepsin.

In our present work, treatment with L-citrulline protected the gastric mucosa from damage by increasing the mucin content significantly as compared to IND group. The increased gastric mucin following L-citrulline treatment may be due to the observed increase in NO level in the present study since NO is a known stimulant of mucus secretion by activating soluble guanylyl cyclase (50). Also, apparently, the free radicals scavenging property of L-citrulline might contribute in protecting the oxidative damage of gastric mucosa and hence, preventing the decrease in mucin content (47).

Our results of the present study showed that IND administration resulted in significant increase in the gastric MDA levels as compared to the normal control rats. This increase in MDA levels may be attributed to that the ability of IND to induce the reactive oxygen metabolites. These free radicals damage the cellular antioxidant enzymes which lead to oxidative stress in gastric tissue causing damage to key bimolecules such as lipids leading to stimulation of lipid oxidation(28).

As shown in the present results, RAN treatment significantly reversed the IND-induced changes in MDA which is in agreement with Dursun et al.(51). This significant reduction in MDA levels suggested decreased lipid peroxidation and antioxidant activity of RAN. RAN, an antisecretory drug, has often been reported to possess antioxidant and immunosuppressive actions, which may be responsible for its anti-ulcerogenic activity(1).

In our present study, L-citrulline significantly reduced gastric MDA as compared to IND-group, it brought MDA levels closer to normal levels. The mechanism by which L-citrulline decreased the MDA levels could be attributed to its antioxidant effect (47).

In the present study, IND significantly reduced gastric mucosal NO level compared to the normal control group. This finding was in accordance with Fouad et al(52) who reported a decrease in NO level in gastric tissue damage by IND. Adhikary et al. (53) also reported administration of IND was associated with a decrease in NO biosynthesis, as a result of decreased nitric oxide synthase activity 
that was associated with an increase in the extent damage.

In our present study, RAN pretreatment for one week before induction of gastric ulcer by IND, insignificantly affect NO levels as compared to IND group. While, pretreatment with L-citrulline significantly prevented the decrease of NO level in the gastric mucosa is induced by IND. The possible mechanism of the increased NO production by L-citruline was explained previously due to recycling pathway from Lcitrulline to L-arginine and NO (25).

Our experimental results showed that IND significantly reduced gastric mucosal PGE2 levels compared to the normal control group. In agreement with previous data, PG has been shown to be reduced in animals by IND treatment (54). PG, a key molecule that stimulates the complex array of ulcer healing mechanism, gets synthesized in the mucosal cells by COX enzymes (55). IND causes gastric ulcer mostly by inhibiting PG synthesis through inhibition of COX enzymes (13).

The results of the present work showed that pretreatment with RAN alone, for 7 days before the induction of gastric ulcer by IND, insignificantly affect PGE2 synthesis as compared to IND group. While, pretreatment with Lcitrulline was significantly increased PGE2 levels when compared to IND group and RAN pretreated group. The mechanism by which L-citrulline increased PGE2 synthesis might be due to NO recycling pathway as NO has been suggested to activate COX enzymes directly (56).

In the present study, we observed a significant increase in MPO activity in the gastric mucosa following IND administration as compared to the normal control, which confirmed the infiltration and activation of neutrophils in the gastric mucosa produced by IND as the neutrophil infiltration into the gastric mucosal tissue is assessed by MPO activity (42).

In our experimental pretreatment with RAN insignificantly affected MPO activity in the gastric mucosa as compared to IND group. While, Lcitrulline significantly inhibited the increased MPO activity as compared to IND group, which might suggest that L-citrulline inhibited the neutrophil infiltration into the gastric tissue (57).

In the present study, L-citrulline significantly increased $\mathrm{HO}$ activity in rat gastric mucosa as compared to IND group. $\mathrm{HO}$ is an inducible stress protein is implicated in cytoprotection in various organs via the anti-inflammatory, antiapoptotic, antioxidant and anti-proliferative actions of one or more of its three products carbon monoxide, biliverdin and free iron (58). Uc et al.(59) reported that $\mathrm{HO}$ protects against irritant-induced gastric lesions. The mechanism by which L-citrulline increased $\mathrm{HO}$ activity in gastric mucosa might be attributed to NO production as it was proved that NO acts as HO-1 inducer (58).

Our results showed that the combination between RAN and L-citrulline had more efficacy in attenuation of gastric ulceration induced by IND, U.I. was more significantly decreased associated with higher significant P.I. (87.30\%) when compared to treatment with either RAN or L-citrulline alone. The combination resulted in more significant decrease of volume of gastric juice, free and total acidity and pepsin activity associated with more significant increase of gastric $\mathrm{pH}$ as compared to either treatment with RAN or L-citrulline alone while, mucin content also 
significantly increased as compared to RAN treated group, but no significant change as compared to L-citrulline treated group.

Also, co-administration of RAN and L-citrulline produced more significant decrease in MDA level as compared to treatment with either RAN or Lcitruuline alone. The results showed that the RAN and L-citrulline co-treatment produced more significant increase in PGE2 synthesis as compared to RAN treated group but no significant difference as compared to L-citrulline treated group.

Also, our results proved that co-administration of RAN and L-citrulline produced more significantly increase in NO production as compared to treatment with either RAN treated group or L-citrulline treated group.

Finally, the results of the present work showed that co-administration of RAN and L-citrulline significantly decreased the MPO activity and significantly increased $\mathrm{HO}$ activity as compared to RAN treated group, but, no significant difference as compared to L-citrulline treated group.

The more efficient gastroprotective effect due to combination of both RAN and L-citrulline might be explained by their synergetic effect.

\section{Conclusions:}

Pretreatment with L-citrulline can protect INDinduced gastric ulceration due to its antioxidant effect, and increasing the mucin content, increasing NO production via citrulline-NO cycle, increasing PGE 2 synthesis and HO activity, while, inhibiting neutrophil infiltration that assayed by decreasing the activity of gastric MPO, and reduction of gastric mucosal lipid peroxidation (MDA). The protection afforded by Co-treatment of L-citrulline and RAN was found to be better than that of L-citrulline alone or RAN alone. Consequently, L-citrulline can be used together with RAN for the treatment of gastric ulcer.

\section{Acknowledgments:}

The authors would like to thank Dr Amal Abd El Salam, professor of department of anatomy, for her kind help in doing the pyloric ligation and removal of gastric tissue for analysis. Also, Many thanks for Dr. Eman El Saed, the assistant professor of pathology for her help in the macroscopic examination of gastric mucosal lesions.

\section{REFERENCES}

1. Sharkawi SM, El-Sherbiny GA, Ain- Shoka AA, El-Sayed ME: Prophylactic role of echinacea, green tea and boswellia extracts in pyloric ligation-induced gastric ulcer in rats. Brit J Pharmacol Toxicol. 3(5): 197-204, 2012.

2. Ode OJ: The antiulcer activities of the methanol extract of Cassia singueana leaves using indomethacin-induced gastric ulcer model in rats. J Adv Sci Res. 2(3): 66-9, 2011.

3. Mejia A, Kraft WK: Acid peptic diseases: pharmacological approach to treatment. Expert Rev Clin Pharmacol. 2(3): 295-314, 2009.

\section{Awaad AS, El-Meligy RM, Soliman GA:} Natural products in treatment of ulcerative colitis and peptic ulcer. Journal of Saudi Chemical Society.17 (1): 101-24, 2013.

\section{Cuevas VM, Calzado YR, Guerra YP, Yera} AO, Despaigne SJ, Ferreiro RM, Quintana DC: Effects of grape seed extract, vitamin C, and vitamin $\mathrm{E}$ on ethanol- and aspirin-induced ulcers. Advances in Pharmacological Sciences. 2011: 740687, 6 pages, 2011. 
6. Silva, FV, Guimaraes AG, Silva ERS, Sousa-Neto BP, Machado FDF, QuintansJunior LJ, Arcanjo DDR, Oliveira FA, Oliveira RCM: Anti-inflammatory and antiulcer activities of carvacrol, a monoterpene present in the essential oil of Oregano. J. Med. Food. 15: 984-91, 2012.

7. Lanza FL, Chan FK, Quigley EM: Guidelines for prevention of NSAID-related ulcer complications. Am J Gastroenterol. 104(3):728$38,2009$.

8. Luther J, Higgins PD, Schoenfeld PS, Moayyedi P, Vakil N, Chey WD: Empiric quadruple vs. triple therapy for primary treatment of Helicobacter pylori infection: Systematic review and meta-analysis of efficacy and tolerability. Am J Gastroenterol. 105 (1): 65-73, 2010.

9. Krysiak R, Okopień B, Herman ZS: Advances in the diagnosis and treatment of ZollingerEllison syndrome. Pol Merkur Lekarski. 33(193):5-12, 2012.

10. Yadav SK, Sah AK, Jha RK, Sah P, Shah DK: Turmeric (curcumin) remedies gastroprotective action. Pharmacogn Rev. 7(13): 42-6, 2013.

\section{Kuramoto T, Umegaki E, Nouda S,} Narabayashi K, Kojima Y, Yoda Y, Ishida K, Kawakami K, Abe Y, Takeuchi T, Inoue T, Murano M, Tokioka S, Higuchi K: Preventive effect of irsogladine or omeprazole on non-steroidal anti-inflammatory druginduced esophagitis, peptic ulcers, and small intestinal lesions in humans, a prospective randomized controlled study. BMC Gastroenterol. 13:85, 8 pages, 2013.
12. Taye A, Saad AH: Role of rosiglitazone as a gastroprotective agent against indomethacininduced gastric mucosal injury in rats. Gastroenterology Research. 2(6):324-32, 2009.

13. Thong-Ngam D, Choochuai S, Patumraj S, Chayanupatkul M, Klaikeaw N: Curcumin prevents indomethacin-induced gastropathy in rats. World J Gastroenterol. 18 (13):1479-84, 2012.

14. Ghalib R, Falah A, Ahmad A: Ulcerogenic effects of NSAIDs on gastric mucosa: comparison between selective and non-selective Cox2 inhibitors; indomethacin VS rofecoxib. Medical Journal of Babylon. 8(2): 197-205, 2011.

15. Schwedhelm E, Maas R, Freese R, Jung D, Lukacs Z, Jambrecina A, Spickler W, Schulze F, Böger RH: Pharmacokinetic and pharmacodynamic properties of oral L-citrulline and L-arginine: impact on nitric oxide metabolism. Br J Clin Pharmacol. 65:51-9, 2008.

16. Collins JK, Wu G, Perkins-Veazie P, Spears K, Claypool PL, Baker RA, Clevidence BA: Watermelon consumption increases plasma arginine concentrations in adults. Nutrition. 23:261-6, 2007.

17. Yi L, Lingshan G, Cui Y, Xiaoxing Y, JunnianZ: A preliminary study on protective effect of L-citrulline against ischemiareperfusion induced gastric mucosal lesions in rat. Indian J Pharmacol. 44(1): 31-35, 2012.

18. Tarazona-Díaz MP, Alacid F, Carrasco M, Martínez I, Aguayo E: Watermelon juice: Potential functional drink for sore muscle relief in athletes. J. Agric. Food Chem. 61 (31): 75228, 2013. 
19. Ventura G, Noirez P, Breuillé D, Godin JP, Pinaud S, Cleroux M, Choisy C, Le Plénier S, Bastic V, Neveux N, Cynober L, Moinard C: Effect of citrulline on muscle functions during moderate dietary restriction in healthy adult rats. Amino Acids. 45(5):1123-31, 2013.

20. Marini JC, Stoll B, Didelija IC, Burrin DG: De novo synthesis is the main source of ornithine for citrulline production in neonatal pigs. Am J Physiol Endocrinol Metab. 303(11):E1348-53, 2012.

\section{Swamy M, Wan Roslina WY, Sirajudeen} KNS, Zulkarnain M, Chandran, G: Decreased glutamine synthetase, increased citrulline-nitric oxide cycle activities and oxidative stress in different regions of brain in epilepsy rat model. J Physiol Biochem. 67:105$13,2011$.

22. Fleissner F, Thum T: Critical role of the nitric oxide/reactive oxygen species balance in endothelial progenitor dysfunction. Antioxid Redox Signal. 15(4):933-48, 2011.

23. Alok B, Kumar R, Dabas V, Alam N: Evaluation of anti-ulcer activity of Citrullus Lanatus seed extract in Wistar albino rats. International Journal of Pharmacy and Pharmaceutical Sciences. 4: Suppl 5: 135,2012.

24. Oluwole FS, Balogun ME Temitope AG: Antisecretory effects of watermelon (Citrullus lanatus) juice in male albino rats. Annual Review \& Research in Biology. 3(4): 358-366, 2013.

25. A, Kraft WK: Acid peptic diseases: pharmacological approach to treatment. Expert Rev Clin Pharmacol. 2(3): 295-314, 2009.

26. Demirkan K, Bozkurt B, Karakaya G, Kalyoncu AF: Anaphylactic reaction to drugs commonly used for gastrointestinal system diseases: 3 case reports and review of the literature. J Investig Allergol Clin Immunol. 16:203-9, 2006.

27. Shimizu N, Yamaguchi M, Uesu K, Goseki T, Abiko Y: Stimulation of prostaglandin E2 and interleukin-1ß production from periodontal ligament cells of old rat subjected to mechanical stress. J. Gerontol. A Biol. Sci. Med. Sci. 55: B489-95, 2000.

28. Moustafa YM, Khoder DM, El-Awady EE, Zaitone SA: Sildenafil citrate protects against gastric mucosal damage induced by indomethacin in rats. Eur Rev Med Pharmacol Sci. 17(2):179-88, 2013.

29. Odabasoglu F, Cakir A, Suleyman H, Aslan A, Bayir $\quad$ Y, Halici $\quad$ M, Kazaz $\quad$ C: Gastroprotective and antioxidant effects of usnic acid on indomethacin-induced gastric ulcer in rats. J Ethnopharmacol. 103(1):59-65, 2006.

30. Liu Y, Tian X, Gou L, Fu X, Li S, Lan N, Yin X: Protective effect of 1-citrulline against ethanol-induced gastric ulcer in rats. Environ Toxicol Pharmacol. 34 (2): 280-7, 2012.

31. Alumets J, Ekelund M, Hakanson R, Hedenbro J, Rehfeld JF, Sundler F, Vallgren S: Gastric acid response to pylorus ligation in rats: is gastrin or histamine involved? J. Physiol. 323:145-56, 1982.

32. Peskar BM, Ehrlich K, Peskar B: A Role of ATP-sensitive potassium channels in prostaglandin-mediated gastroprotection in the rat. J. Pharmacol. Exp. Ther. 301(3):969-74, 2002.

33. Hano J, Bugajski J, Danek L: Effect of adrenergic blockade on gastric secretion altered 
by catecholamines in rats. Arch. Immunol. Ther. Exp. (Warsz). 24(4):507- 24, 1976.

34. Moore EW: Determination of $\mathrm{pH}$ by the glass electrode: $\mathrm{pH}$ meter calibration for gastric analysis. Gastroenterology. 54(4): 501-7, 1968.

35. Hara N, Hara Y, Natsume Y, Goto Y: Gastric hyperacidity and mucosal damage caused by hypothermia correlate with increase in GABA concentrations of the rat brain. Eur. J. Pharmacol. 194(1):77, 1991.

36. Feldman M: Gastric secretion, normal and abnormal. In: Feldman M, Scharschmidt BF , Sleisenger MH Sleisenger \& Fordtran's Gastrointestinal and Liver Disease : Pathophysiology/ Diagnosis/ Management. 6th edn. WB Saunders Co, Philadelphia. P.587-603, 1998.

37. Sanyal AR, Denath OK, Bhattacharya SK, Gode KD: The effect of cyproheptadine on gastric acidity. In: Pfeiffer CJ (ed). Peptic ulcer. Scandinavian University Books, Munksgaard, Copenhagen. p. 312-8, 1971.

38. Beneyto JE, Colomé J: Direct spectrophotometric determination of mucin disulfide linkages. Anal Biochem. 58 (2): 62431, 1974.

39. Mihara M, Uchiyama M: Determination of malonaldehyde precursor in tissues by thiobarbituric acid test. Anal. Biochem. 86(1):271-8, 1978.

40. Sastry KV, Moudgal RP, Mohan J, Tyagi JS, Rao GS: Spectrophotometric determination of serum nitrite and nitrate by coppercadmium alloy. Anal. Biochem. 306 (1):79-82, 2002.

41. Arvind P, Papavassiliou ED, Tsioulias GJ, Qiao L, Lovelace CI, Duceman B, Rigas B: Prostaglandin E2 down-regulates the expression of HLA-DR antigen in human colon adenocarcinoma cell lines. Biochemistry. 34(16):5604-9, 1995.

42. Bradley PP, Priebat DA, Christensen RD,

Rothstein G: Measurement of cutaneous inflammation: estimation of neutrophil content with an enzyme marker. J. Invest. Dermatol. 78 (3): 206-9, 1982.

43. Ishikawa K, Sato M, Yoshida T: Expression of rat heme oxygenase in Escherichia coli as a catalytically active. Full-length form that binds to bacterial membrances. Eur J Biochem. 202: 161-5, 1991.

44. Kalra P, Sharma S, Suman, Kumar S: Antiulcer effect of the methanolic extract of Tamarindus indica seeds in different experimental models. Pharm Bioallied Sci. 3(2): 236-41, 2011.

45. Banji D, Singh J, Banji OJ: Scrutinizing the aqueous extract of leaves of pedalium murex for the antiulcer activity in rats. Pak. J. Pharm. Sci. 23(3):295-9, 2010.

46. Norlen P, Ericsson P, Kitano M, Ekelund M, Hakanson R: The vagus regulates histamine mobilization from rat stomach ECL cells by controlling their sensitivity to gastrin. J. Physiol. 564(3): 895-905, 2005.

47. Tripathi P, Misra MK: Therapeutic role of Larginine on free radical scavenging system in ischemic heart diseases. Indian $\mathrm{J}$ Biochem Biophys. 46(6):498-502, 2009.

48. Liu Y, Fu X, Gou L, Li S, Lan N, Zheng Y, Yin X: L-citrulline protects against glycerolinduced acute renal failure in rats. Ren Fail. 35(3):367-73, 2013.

49. Morsy MA, Heeba GH, Abdelwahab SA, Rofaeil RR: Protective effects of nebivolol 
against cold restraint stress-induced gastric ulcer in rats: role of NO, HO-1, and COX-1,2. Nitric Oxide. 27 (2):117-22, 2012.

\section{Niv Y, Boltin D, Halpern M, Cohen M, Levi}

Z, Vilkin A, Morgenstern S, Manugian V, St Lawrence E, Gagneux P, Batra SK, Ho SB: Membrane-bound mucins and mucin terminal glycans expression in idiopathic or Helicobacter pylori, NSAID associated peptic ulcers. Dig Dis Sci. 57(10):2535-44, 2012.

51. Dursun H, Albayrak F, Bilici M, Koc F, Alp HH, Candar T, Kukula O: Gastroprotective and antioxidant effects of opipramol on indomethacin-induced ulcers in rats. Yakuga. Zasshi. 129(7): 861-9, 2009.

52. Fouad AA, Al-Sultan AI, Yacoubi MT, Gomaa W: Ameliorative effects of telmisartan in diabetic rats with indomethacin induced gastric ulceration. Eur J Pharmacol. 637(13):162-70, 2010.

53. Adhikary B, Yadav SK, Chand S, Bandyopadhyay SK, Chattopadhyay S: Black tea and theaflavins suppress various inflammatory modulators and i-NOS mediated nitric oxide synthesis during gastric ulcer healing. Free Radic Res. 45(7):767-78, 2011.

54. Takeuchi K: Pathogenesis of NSAIDinduced gastric damage: importance of cyclooxygenase inhibition and gastric hypermotility. World J Gastroenterol. 18(18):2147-60, 2012.

55. Balamurugan K, Sakthidevi G, Mohan VR: Antiulcer activity of Polycarpaea corymbosa (L.) Lam. whole plant extracts (Caryophyllaceae) Int J Biol Med Res. 4(3): 3379- 82, 2013.
56. Ye Y, Martinez JD, Perez-Polo RJ, Lin Y, Uretsky BF, Brinbaum Y: The role of eNOS, iNOS, and NF-kB in upregulation and activation of cyclooxy-genase-2 and infarct size reduction by atorvastatin. Am J Physiol Heart Circ Physiol. 295: H343-51, 2008.

57. Sureda A, Cordova A, Ferrer MD, Tauler P, Perez G, Tur JA, Pons A: Effects of Lcitrulline oral supplementation on polymorphonuclear neutrophils oxidative burst and nitric oxide production after exercise. Free Radic. Res. 43(9): 828-35, 2009.

58. Zhu X, Fan WG, Li DP, Kung H, Lin MC: Heme oxygenase-1 system and gastrointestinal inflammation: a short review. World J Gastroenterol. 17 (38): 4283-8, 2011.

59. Uc A, Zhu X, Wagner BA, Buettner GR, Berg DJ: Heme oxygenase- 1 is protective against nonsteroidal anti-inflammatory druginduced gastric ulcers. J Pediatr Gastroenterol Nutr. 54: 471-76, 2012 


\section{ملخص البحث}

الهدف من هذا البحث : معرفة تأثثير ل-سيترولين ور انتيدين على قرحة المعدة المستحدثة بالاندوميثاسين في ذكور الفئران البيضاء من النوع وستر من البحت طرق البحث: نم إجر اء البحث على 50من ذكور الفئران البيضاء من النوع وستر، وزنها بين 180-220جم، تم تقسيمها إلى خمس

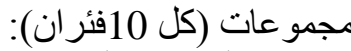

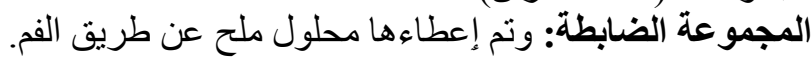

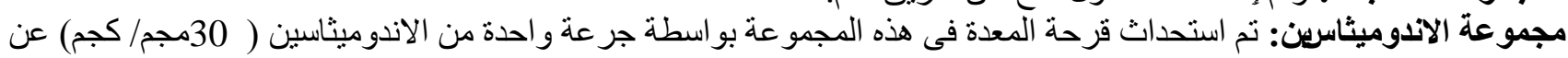
طريق الفم الآن مجموعة الاندوميثاسرين+رانتيدين: وقد تم معالجنها بالر انتيدين (50مجم/كجم) عن طريق الفم لمدة 7 أيام قبل استحداث قرحة المعدة بالاندوميثاسين.

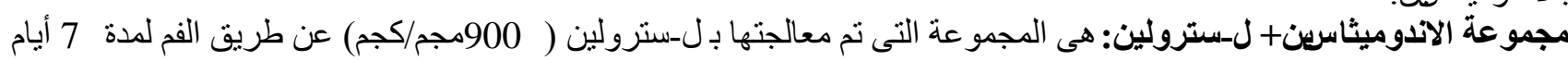

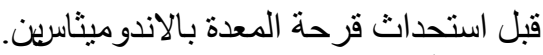

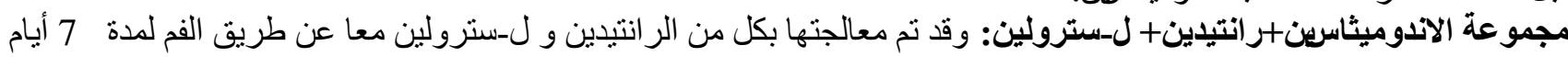
قبل استحداث قرحة المعدة بالاندوميثاسين.

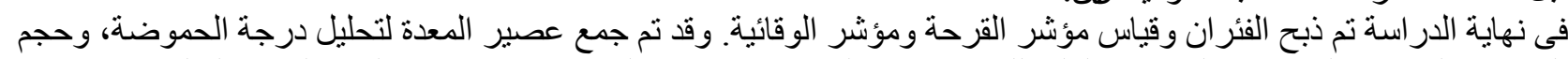

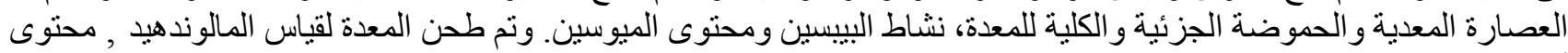

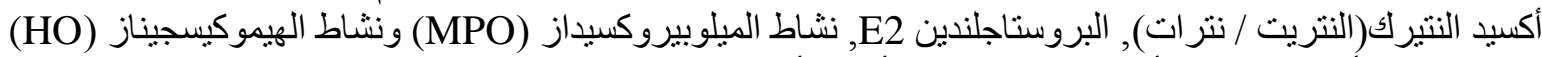

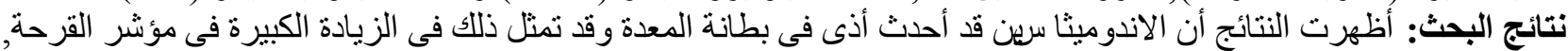

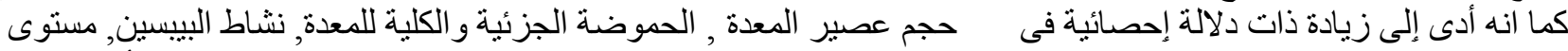

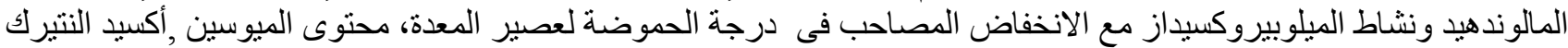

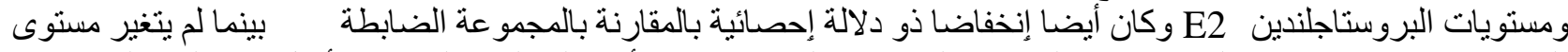

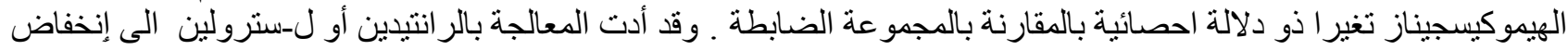

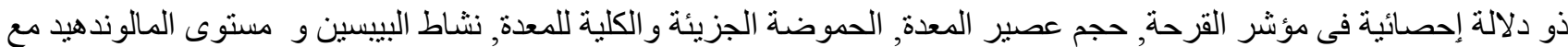

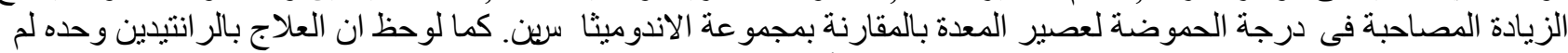

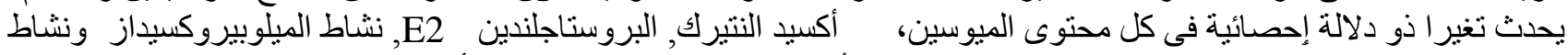

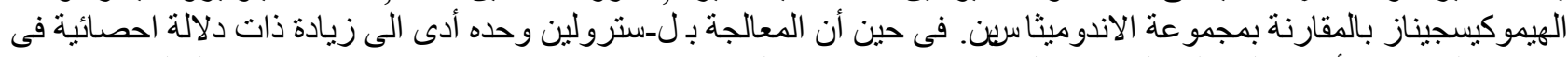

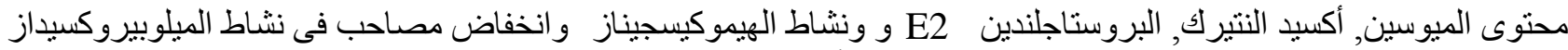

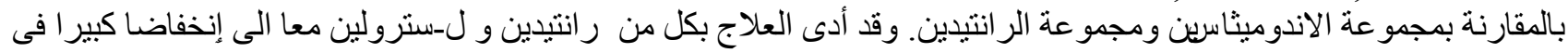

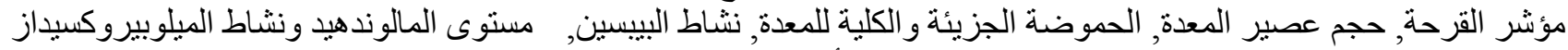

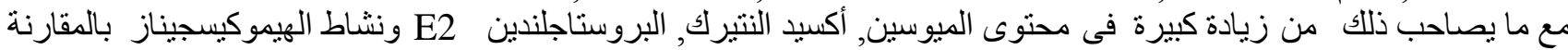
بمجمو عة الاندو ميثاسنين ومجمو عة زئرة الر انتيدين.

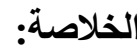

العلاج بكل من ر انتيدين و ل-سنرولين معا يحمل إمكانات جيدة ضد قرحة المعدة المستحدث بالاندوميثاسين أفضل من كل دو اء على 